\title{
The Nigerian Solar Photovoltaic Industry; Policies and Schemes for achieving Grid parity
}

This paper was downloaded from TechRxiv (https://www.techrxiv.org).

LICENSE

CC BY-NC-SA 4.0

SUBMISSION DATE / POSTED DATE

$12-02-2022$ / 22-02-2022

CITATION

Udosen, David (2022): The Nigerian Solar Photovoltaic Industry; Policies and Schemes for achieving Grid parity. TechRxiv. Preprint. https://doi.org/10.36227/techrxiv.19165394.v1

DOI

10.36227/techrxiv.19165394.v1 


\title{
The Nigerian Solar Photovoltaic Industry: Policies and Schemes for achieving Grid parity
}

\author{
David Udosen \\ Shobab Energy \\ Nigeria \\ david@shobabenergy.com | davidudosen@gmail.com
}

\begin{abstract}
With increased awareness on the debilitating effects of greenhouse gas emissions (resulting majorly from the combustion of fossil fuels) coupled with the increasing need to explore more sustainable energy sources to cater for the proliferating global energy needs, there would be no better time to pursue a cause in solar photovoltaic (PV) energy generation. Thankfully, due to subsidies and technological advancement, $P V$ systems' cost are at an all-time low. However, the government and various stakeholders have roles to play in ensuring competitiveness of the PV industry with conventional generating companies (Gencos). This paper outlines the necessary policies and schemes that will aid the Nigerian PV industry in achieving competitiveness and Grid parity (traditionally defined as a situation where the generation cost of Solar PV electricity equals the cost of conventional electricity sources) with conventional Gencos and retail electricity prices.
\end{abstract}

Keywords-Solar PV, Grid parity, Feed-in Premiums, Feed-in Tariffs

\section{INTRODUCTION}

Located just above the equator, Nigeria receives a considerably large amount of direct solar irradiation. Average solar radiation levels are estimated to be about $18.9 \mathrm{MJ} / \mathrm{m}^{2}$ day (5.3 $\mathrm{kWh} / \mathrm{m}^{2}$-day) [1]. Thus, there is a potential of about $17,459,215.2 \mathrm{TJ} /$ day worth of solar energy generation across its land mass of $923,768 \mathrm{~km}^{2}$ [2]. With current industrialization, driven by non-renewable energy sources, tapping into these huge potential would be necessary to reduce greenhouse gas emission levels while exploring sustainable alternatives.

Engineering an effective renewable energy policy that supports continuous stability and security of electricity supply requires the development of measures that are simple and easy-to-understand. As such, every successful renewable energy support scheme should have these five elements:

- An assured reward system enforced by the government that attract investors and generally lower industry costs.

- Clear and simple procedure for obtaining development permission.

- $\quad$ Preferential treatment for connecting to the grid and a means of identifying the developer responsible for the connection at any given time.

- Clear plan on how premiums and incentives are calculated and paid.

- High level of public awareness and support.

\section{POLICIES AND SCHEMES FOR SUSTENABLE PHOTOVOLTAIC (PV) DEVELOPMENT}

\section{A. Feed-in Premium (FiP)}

Under a feed-in premium scheme, renewable energy sources (RES) developers receive a premium on top of the normal market prices for electricity generation. This premium is either fixed (i.e. independent of market prices) or varying (changes with changes in market price). Fixed FiP have simpler structures but there are risks of overpaying (like when the normal market prices are high) or underpaying (like when the normal prices are low) RES developers [3, 4]. As a result, fixed FiP usually have predetermined payment plans for different market prices.

For varying FiP, payment plans are usually determined by market prices and are calculated from a reference plan (usually from the current payment plan). These plans are reviewed periodically (say every month) to prevent abnormalities (as is the case when developers are overpaid or underpaid).

\section{B. Feed-in Tariffs (FiT)}

The fact that Germany with a rather temperate climate boasts of a world-renown solar electricity market and a thriving PV industry is shocking. However, many agree that a Feed-in Tariff policy - a policy that ensures that premium is paid for every amount of renewable electricity that is injected into the grid [5] - is responsible for this trendsetters [6]. This has greatly reduced the cost of generating electricity when compared with other parts of the world. Table 1 summarizes the FiT workflow.

\section{TABLE I. HOW FIT WORKS}

\begin{tabular}{|c|c|}
\hline Institution & Roles \\
\hline Government (GOV) & $\begin{array}{ll}\text { - } & \text { Setup legal framework for grid } \\
\text { connection } \\
\text { - } & \text { Sets (decreasing) tariffs for all RE } \\
\text { sources } \\
\text { - } & \text { No involvement in cash flow }\end{array}$ \\
\hline $\begin{array}{l}\text { Renewable energy } \\
\text { developers (RED) }\end{array}$ & $\begin{array}{ll}\text { - } & \text { Follows technical standards for grid } \\
\text { connection and operation } \\
\text { - } & \text { Reports every technical failure directly to } \\
\text { TM } \\
\text { - }\end{array}$ \\
\hline $\begin{array}{l}\text { Transmission } \\
\text { operator (TM) }\end{array}$ & $\begin{array}{ll}\text { - } & \text { Guarantees grid connection } \\
\text { - } & \text { Forecasts the total estimated RE } \\
\text { electricity generation } \\
\text { - } \\
\text { Calculates the total generated RE } \\
\text { electricity } \\
\text { - } \quad \text { Calculates needed total Feed-in Tariffs } \\
\text { based on estimated RE electricity } \\
\text { production } \\
\text { Breaks down the additional costs per } \\
\text { kWh for distributor } \\
\text { - Collects the money from Distributors } \\
\text { (DIS) } \\
\text { - Pays Feed-in Tariffs to RED }\end{array}$ \\
\hline Distributor (DIS) & $\begin{array}{l}\text { - } \quad \text { Collects money from consumer (based on } \\
\text { forecast of TM) and transfers it to TM } \\
\text { - Organizes billing for consumer } \\
\text { distributes RE electricity }\end{array}$ \\
\hline Consumer (CON) & $\begin{array}{l}\text { - } \begin{array}{l}\text { Pays electricity bill (including the extra } \\
\text { charge for Feed-in Tarifs) }\end{array} \\
\text { - } \quad \text { Sets (decreasing) tariffs for all RE } \\
\text { sources } \\
\text { - } \quad \text { No involvement in cash flow }\end{array}$ \\
\hline
\end{tabular}


Adapting the FiT policy to meet specific targets is key in promoting the development of solar electricity in Nigeria. The concept requires that developers of solar electricity:

- Are allowed to feed in generated solar PV power into public or minigrid networks.

- Are paid a premium that adequately shows solar PV generation benefits compared to electricity generated from fossil fuels for every $\mathrm{kWh}$ generated.

- Are paid these reviewed premiums for a stipulated period.

\section{OTHER DRIVERS FOR DEVELOPING A PROFITABLE PV MARKET}

\section{A. Streamlining administration procedures}

A good administration will be needed for two reasons; to prevent high costs of projects induced by bureaucracy and to prevent grid parity imbalance by over-supporting the PV industry. Managements and policy engineers will have to ensure the following when drawing up policies:

\section{1) Evaluate administrative process and procedure.}

Policymakers should strive for a process where authorizations are clear, straightforward, simple and costeffective. Administrative delays or redundant requirements that developers contact multiple agencies or government bodies for approval increase the overall cost of new projects. Licensing agreements and contracts should be provided turnkey. Additionally, effective supervision must be ensured.

\section{2) Ensure reduced lead times}

Lead times, especially for small-scale investments, must be reduced to a minimum as delay in contracting process could result in a total abandon of the project due to a perceived decrease in profitability or an outright loss of interest for the investor. This stalls growth and makes the project less attractive. There should be bills for automatic approval of projects (especially small scale projects) if contracting bodies fail to meet set deadlines for approvals in the face of all available requirements.

\section{B. Guaranteeing Efficient Grid Connection}

An efficient means that guarantees the transportation and subsequent sales of generated solar PV (otherwise called an evacuation system) must be installed and properly functioning as these are crucial to any hopes of the developer getting returns on investments. More recently, evacuation has become a worrying obstacle to increasing power generation as transmission lines have a maximum capacity of about $5 \mathrm{GW}$ [7]. This could cause delays to project implementation and as a result, increase its overall cost. Also, equipment for connection to the national grid may drive production costs further higher. The following are recommended:

\section{1) Evaluate evacuation process.}

Evaluation should focus on clearness; providing allinclusive information on guaranteed lead times, cost and revenue sharing between the PV generator and the distribution company.

\section{2) Set minimal timeline for grid-connection.}

Electricians should be adequately trained and accredited in small-scale system installation, maintenance, trouble- shooting and grid connection and readily available for use to reduce project lead times.

3) Issue operating licenses to qualified PV developers. It is almost certain that such policy announcements follow waves of development requests in magnitudes that are almost incomprehensible and unmanageable. This situation can be forestalled by ensuring that only qualified developers are given the green light. Licenses and operation permits should only last for a period of time upon which renewal will be based on the continual performance of the developer in alignment with previously set standards.

4) Ensure capacity of network operators.

For generated PV electricity to reach the end users (consumers), it must be transmitted by various transmission and distribution equipment. This equipment is usually expensive and require maintenance and upgrade. If the PV industry is expected to thrive, support must also be given to the transmission and distribution companies.

\section{CONCLUSIONS AND RECOMMENDATIONS}

It has been seen that robust policing will be vital if an accelerated growth in the Nigerian PV industry is expected. Below are key recommendations policy-makers should adopt to ensure that PV attains grid parity in minimal time.

- Feed-in Tariffs or similar policies adapted to suit local needs should be used.

- Ensuring that the true cost of RES and NRES for generating electricity are clearly represented in the consumer's electricity bill.

- Develop a sustainable market by periodically reviewing industry growth and support schemes and adjusting support levels accordingly.

\section{REFERENCES}

[1] Energy Commission of Nigeria, Abuja, "National Energy Policy," 10 September 2003. [Online]. Available: osgf.gov.ng/payload?id=ffobfcf6-2376-4a37-9fe6-51b73e550fbc

[2] A. A. Adeyanju and K. Manohar, "Assessment of Solar Thermal Energy Technologies in Nigeria," in 2011 IEEE Green Technologies Conference (IEEE-Green), Baton Rouge, Louisiana, 2011.

[3] L. Kitzing, C. Mitchell and P. E. Morthorst, "Renewable energy policies in Europe: Converging or diverging?," Energy Policy, vol. 51, no. Renewable Energy in China, pp. 192-201, 2012.

[4] A. Purkus, E. Gawel, M. Deissenroth, K. Nienhaus and S. Wassermann, "Market integration of renewable energies through direct marketing - lessons learned from the German market premium scheme," 16 April 2015. [Online]. Available: https://doi.org/10.1186/s13705-015-0040-1. [Accessed 25 January 2020].

[5] J. Cornfeld and A. Sauer, "Amy," March 2010. [Online]. Available: https://www.eesi.org/files/feedintariff_033110.pdf. [Accessed 25 January 2020].

[6] World Future Council, "The German Feed-In Tariff," futurepolicy.org, [Online]. Available: https://www.futurepolicy.org/climate-stability/renewableenergies/the-german-feed-in-tariff/. [Accessed 22 January 2020].

[7] The World Bank, A Proposed Credit in the Amount of SDR 86.2 Million (US\$122 Million Equivalent) and a Scale-Up Facility Credit in the Amount of US\$364 Million to The Federal Republic Of Nigeria for an Electricity Transmission Project, International Development Association, 2018. 